\title{
Deep solidarity: Broadening the basis of transformation
}

\begin{tabular}{|c|c|}
\hline \multicolumn{2}{|c|}{$\begin{array}{l}\text { Authors: } \\
\text { Joerg Rieger }\end{array}$} \\
\hline $\begin{array}{l}\text { Affiliations: } \\
{ }^{1} \text { Graduate Prog } \\
\text { Divinity School } \\
\text { University, Unit }\end{array}$ & $\begin{array}{l}\text { gram of Religion, } \\
\text {, Vanderbilt } \\
\text { ted States }\end{array}$ \\
\hline \multicolumn{2}{|c|}{$\begin{array}{l}{ }^{2} \text { Independent Researcher, } \\
\text { United States }\end{array}$} \\
\hline \multicolumn{2}{|c|}{$\begin{array}{l}{ }^{3} \text { Department of Practical } \\
\text { Theology, Faculty of } \\
\text { Theology, University of } \\
\text { Pretoria, South Africa }\end{array}$} \\
\hline \multirow{2}{*}{\multicolumn{2}{|c|}{$\begin{array}{l}\text { Research Project Registration: } \\
\text { Project Leader: S.F. de Beer } \\
\text { Project Number: } 86233689\end{array}$}} \\
\hline & \\
\hline \multicolumn{2}{|c|}{$\begin{array}{l}\text { This research is part of the } \\
\text { research project, 'Social } \\
\text { Justice and Reconciliation', } \\
\text { which is directed by Dr } \\
\text { Stephan de Beer, Director of } \\
\text { the Centre for Contextual } \\
\text { Ministry and member of the } \\
\text { Department of Practical } \\
\text { Theology, Faculty of Theology, } \\
\text { University of Pretoria. }\end{array}$} \\
\hline \multicolumn{2}{|c|}{$\begin{array}{l}\text { Corresponding author: } \\
\text { Joerg Rieger, } \\
\text { j.rieger@vanderbilt.edu }\end{array}$} \\
\hline $\begin{array}{l}\text { Dates: } \\
\text { Received: } 31 \mathrm{~N} \\
\text { Accepted: } 05 \mathrm{~A} \\
\text { Published: } 27 \mathrm{I}\end{array}$ & $\begin{array}{l}\text { Mar. } 2017 \\
\text { Aug. } 2017 \\
\text { Nov. } 2017\end{array}$ \\
\hline \multicolumn{2}{|c|}{$\begin{array}{l}\text { How to cite this article: } \\
\text { Rieger, J. \& Henkel-Rieger, } \\
\text { 2017, 'Deep solidarity: } \\
\text { Broadening the basis of } \\
\text { transformation', HTS } \\
\text { Teologiese Studies/ } \\
\text { Theological Studies 73(3), } \\
\text { a4578. https://doi.org/ } \\
\text { 10.4102/hts.v73i3.4578 }\end{array}$} \\
\hline Read onlin & \\
\hline 口9a & $\begin{array}{l}\text { Scan this QR } \\
\text { code with your } \\
\text { smart phone or } \\
\text { mobile device } \\
\text { to read online. }\end{array}$ \\
\hline
\end{tabular}

Across the globe, conditions of labour are worsening, providing both challenges and opportunities. As labour is one of the places where the intersectionality of race, ethnicity, gender, sexuality, and class is always at work, new models of resistance are created here as well. Deep solidarity describes what happens when the $99 \%$ who have to work for a living (including people who are excluded from the job market) realise what they have in common, in order to employ their differences productively in the struggle. In this article, a theologian and a labour and community organiser work together showing how the Abrahamic religious traditions and developments in the world of labour help us to shape deeper forms of solidarity.

The neoliberal capitalist economy, where winner takes all, is putting more and more people in the same boat. The vast majority of us have to work for a living while the work that we do is fraught with tensions. Growing pressures at work are linked with capitalist 'lean and mean production', increases in the pace of work, less freedom for self-determination and creativity, and less support. Add to that reductions in benefits, job security and that fact that even many middle-class people in the United States are often only a few pay cheques away from homelessness. Even if some of us are not experiencing these pressures personally, they affect us through what is happening to many of our partners, our children, our parents and our communities. These are the foundations for what we have been calling deep solidarity. ${ }^{1}$

Deep solidarity recognises that the system works for the few rather than for the many and that nothing will change unless more of the many come together. Deep solidarity does not mean that we are all alike or that our differences do not matter anymore, just the opposite: deep solidarity allows us to deal with our differences more constructively and put them to work for a common cause. Moreover, deep solidarity realises that we need to pay attention to what happens in those places where the pressure is greatest and where all other forms of oppression along the lines of race, ethnicity, gender, sexuality, etc., are bundled. In this chapter, we will argue that the world of labour is where things can often be seen most clearly and resistance is being organised, which is why solidarity is reprimanded more severely when it is related to labour issues.

When solidarity among working people results in formal efforts to form alliances and unions, companies in the United States often respond in drastic ways. ${ }^{2}$ Many hire so-called labour relations experts - less officially known as 'union busters' - who are charged with diffusing these efforts. The methods used by these experts range from requiring workers to attend so-called 'captive audience' meetings and one-on-one conversations to accusations that unions are only after workers' contributions, threats and severe last-minute interventions when a union drive appears to be successful. Unlike union organisers, union busters are granted almost unlimited access to workers, with dominant power and money on their side.

Not surprisingly, conventional acts of charity and even speaking out in advocacy are no match for the old strategy of divide-and-conquer when applied by corporations and their agents. What divide-andconquer seeks to defeat most desperately, therefore, is solidarity. When the adjunct faculty at the New School University in New York City, including a majority of the faculty at the Parsons School of Design, embarked on a unionising campaign with the United Autoworkers, the university administration posted signs that read, 'Are you an artist or an autoworker?' The administration felt so threatened by

1.The term 'deep solidarity' was coined by us in 2011 in response to the Occupy Wall Street Movement (Rieger 2012). For more extended reflections, see Rieger and Pui-lan (2013) and Rieger (2013a).

2.See, for instance, the examples in our book Unified We Are a Force (Rieger \& Henkel-Rieger 2016).

Note: The collection entitled 'Spirit rising: tracing movements of justice', forms part of the 'Faith in the City' research project, hosted by the Centre for Contextual Ministry in the Faculty of Theology, University of Pretoria. Some of the articles were papers presented at the Biennial Consultation on Urban Ministry, hosted by the Institute for Urban Ministry, in collaboration with other organizations, from 17-20 August 2016. The theme of this Consultation was '\#We must rise: healers - dreamers - jesters'.

Copyright: ㄷ 2017. The Authors. Licensee: AOSIS. This work is licensed under the Creative Commons Attribution License. 
artists organising with supportive autoworkers, they retaliated. It is worth noting that artists providing charity, or even speaking out in advocacy, for autoworkers would not be likely to have had the same effect.

Dividing and conquering has a long history in the United States. In 17th-century Virginia, black and white sharecroppers were divided and conquered when the white masters gave the white sharecroppers slightly more privileges and recognition so that white sharecroppers would identify with their white masters rather than their black colleagues. One of the roots of racism in the United States is still surprisingly effective even today. This racism disproportionately serves the white masters rather than their white servants. The truth of the matter is, of course, that in 17th-century Virginia, white sharecroppers and black sharecroppers shared more in common than white sharecroppers and white masters. The solidarity of the oppressed was so threatening to white masters, they incited racism to divide and conquer. When white sharecroppers separated themselves from their black sisters and brothers, the white masters won. Over time, working people began to internalise the divide-and-conquer strategy (Martinot 2003:108-110). ${ }^{3}$ As a South African colleague once put it, racism is still one way in which the class struggle is being fought today.

Sexism is another example of how divide-and-conquer works and how it is internalised. Women often found themselves even more segregated at the workplace than racial minorities, working in jobs where there were no male colleagues. The male-dominated unions of both the American Federation of Labor and the Congress of Industrial Organizations did not make serious efforts to organise women, and women often remained second-class citizens even when they were members of the racially progressive unions. In addition, women continue to be the primary caregivers at home. Non-white women have a longer and deeper history of being affected by sexism than white women, as they were always more likely to participate in the labour force (Yates 2009:151-162). Racism and sexism continue to hurt solidarity even today. Fred Rose is right when he notes that 'if movements do not become aware of the unconscious ways in which they reinforce existing divisions in society, they are likely to encourage them' (Rose 1999:25).

Divide-and-conquer strategies between the middle and the working classes have supported the march to power of the elites in unprecedented ways. While the white working class tends to identify with the white ruling class along the lines of race, the middle class additionally tends to identify with the ruling class along the lines of wealth: both identifications are mistaken, because the differences between someone making $\$ 800000$ a year and someone making \$200 000 a year is greater than the differences between someone making \$200 000 a year and someone making \$20 000 a year. What difference might rethinking solidarity make in these situations?

\footnotetext{
3. Martinot talks about an 'intermediary control stratum', in which both elites and workers share to some extent. He wrote of the formation of this control stratum with reference to Theodore Allen's two-volume work on The Invention of the White Race (Martinot 2010:16-17).
}

\section{Deepening solidarity}

Solidarity pushes us a step beyond advocacy, a concept that is often used in progressive religious circles when they realise that models of charity are too narrow. Rather than merely helping others in need and thus engaging in acts of charity, advocates speak out about the problems that affect others, challenging the powers that be. Yet, while advocacy seeks to address the causes of the problems overlooked by charity, advocacy reaches its limits when advocates fail to understand their deeper connections with those for whom they are advocating. Too many advocates assume that they are somehow above or unaffected by the problems they are addressing, speaking for others out of the goodness of their own hearts. The same is true for some forms of solidarity. In the past, solidarity has sometimes been misunderstood as the privileged supporting the underprivileged. Well-meaning people in the countries of the global North, for instance, have at times declared their solidarity with people in the countries of the global South, without understanding what they might share in common.

One-sided forms of advocacy and solidarity create several problems. One is that those who consider themselves privileged are calling the shots, acting as if they had the ability to fix the problems by themselves. This rarely works, because the problems are usually too big and because the privileged group is not able to understand what is going on without those who are most immediately affected. Moreover, advocates often assume that they are speaking for those who have no voice, without realising that others may have a voice and are using it in their own ways. Another problem has to do with the fact that those who consider themselves privileged might feel like they can walk away from solidarity whenever they had enough because they fail to understand the deeper connections that link them to the struggle.

We are proposing the term 'deep solidarity' to address these problems and to suggest a better way forward. Deep solidarity describes a situation where the $99 \%$ of us who have to work for a living develop some understanding that we are in the same boat. 4 The question is not just, as one Christian theologian put it, 'How can the church maintain integrity in its relationship with workers?' (Wood 2010:198). The question is how faith communities can begin to understand that they are mostly made up of working people, that most of us are workers now and that even what is considered divine appears to be joining us in deep solidarity. Other communities, including the unions and their supporters, can benefit from this perspective as well. To be sure, understanding our deep connections and relationships does not mean that our differences have to be covered up. Just the opposite: deep solidarity allows us to respect our differences and to put them to productive use.

Deep solidarity is possible when the $99 \%$ realise that most of us benefit less and less from the current economic situation and that our relationships shape up differently than we are

4.The language of the $1 \%$ and the $99 \%$ was coined by the Occupy Wall Street movement. It is not an exact number but gives expression to the fact that the vast movement. It is not an exact number but gives expression to the fact that the vast
majority in a capitalist economy has to work for a living and that even middle-class people are not exempt. 
led to believe. In terms of simple math, for instance, someone who earns $\$ 150000$ a year is closer to someone who earns $\$ 15000$ a year than to someone who earns \$500 000 a year the realm where membership in the $1 \%$ barely begins in the United States. Earnings are, of course, merely the tip of the iceberg. What matters is power. Even members of the middle class, including the ones who feel fairly comfortable at the moment, have surprisingly little power over their future: they cannot do much to push back when the corporation requires them to work harder and longer hours, they cannot do much to secure their personal investments, which are subject to ever greater market fluctuations from which mostly the insiders benefit, and they cannot do a whole lot to truly secure their future. Perhaps most important of all is that the middle class can no longer assume that the next generation will still be middle class or better.

In the struggle to support Walmart workers, we quickly learned that 'As goes Walmart so goes the economy'. Even the better jobs are becoming more and more precarious, with the potential of being cut at any time. Today, white-collar workers are often just as affected as blue collar workers by the corporate efforts to maximise profits at all cost. The proletariat is turning into what some have called the 'precariat', a diverse group of people who have to work for a living, including a cross section of the $99 \%$ who are forced to bear the brunt of increasing insecurity, risk and pressure at work (Rehmann 2013:147-152; Standing 2016).

Unfortunately, what happens at the level of work and labour also happens in every other area of life. Like the members of the working-class majority (at $63 \%$ of the population in the United States), members of the middle class (at $35 \%$ of the population in the United States) have less and less power in their communities, whereas the larger donors and philanthropists call the shots in cities and towns, as well as religious communities. Influencing elections is completely out of the reach of individual members of the working and middle classes.

In other words, the middle class finds itself closer to the working class and the poor than ever before. In this climate, solidarity is no longer a matter of the privileged helping the underprivileged; rather, solidarity is a matter of understanding what we have in common and that we need to work together if we want to make a difference not only at work but in any other area of life. For the $99 \%$ working majority, trying to replicate the power of the $1 \%$ is not an option. We will never be able to beat them at their game: the gap is simply too vast. Of course, there are differences with the top $1 \%$ as well, as the difference between millions and billions is much more difficult to grasp than most people realise. ${ }^{5}$ It is very hard to comprehend in financial terms that eight individuals can own as much as the lower half of humanity combined, 3.6 billion people (Reuters News

5.One way to illustrate the difference is to consider that a million seconds is 13 days, while a billion seconds is 31 years. For million dollars in $\$ 100$ bills, a backpack would while a billion seconds is 31 years. For million dollars in $\$ 100$ bills, a backpack
do. For a billion dollars, 10 forklifts would be necessary (Weinstein 2012).
Report 2017); it is virtually impossible to comprehend what that difference means in terms of power and influence.

Not all is lost, however. To the contrary: these sharp differences can help us to develop an understanding of what the rest of us have in common, to resist divide-and-conquer and to reconnect that which belongs together. In the process, we can learn to develop different forms of power, which are not only more powerful than the power of the $1 \%$ but also longer-lasting. Deep solidarity, it seems to us, has the power to make a real difference.

\section{Deep solidarity in the ancient world}

Some of the key figures of our Jewish, Christian and Muslim faith traditions embody deep solidarity. One story of deep solidarity shared by all three Abrahamic traditions is the story of Moses. As the ancient traditions tell us, Moses was a descendant of the Hebrew slaves who was raised as an Egyptian Prince in Pharaoh's court. Things change, however, when he sees the Hebrew slaves being mistreated. According to the book of Exodus, Moses overreacts and kills one of the Egyptian slave masters, an act which does not make Moses a leader, even in the eyes of the Hebrew slaves, who challenge his action (Ex 2:11-14). In exile, Moses learns to live the life of a worker and it takes years before he moves to the next step, developing the skills of an organiser in collaboration with his brother Aaron and his sister Miriam.

The ancient story of the Burning Bush is instructive for our reflections on deep solidarity. In this story, God speaks to Moses out of a bush that is burning but is not consumed. While this miracle is often noted and remembered, the actual speech is not. It bears quoting here:

I have observed the misery of my people who are in Egypt; I have heard their cry on account of their taskmasters. Indeed, I know their sufferings, and I have come down to deliver them from the Egyptians, and to bring them up out of that land to a good and broad land, a land flowing with milk and honey, to the country of the Canaanites, the Hittites, the Amorites, the Perizzites, the Hivites, and the Jebusites. The cry of the Israelites has now come to me; I have also seen how the Egyptians oppress them. So come, I will send you to Pharaoh to bring my people, the Israelites, out of Egypt. (Ex 3:7-10, NRSV)

Deep solidarity is expressed in this passage in God's own actions, who at long last sees and hears what is going on as the Egyptian slave masters wage class struggle against the Hebrews. What is more, God decides to join the struggle for liberation, taking the side of the slaves. And while the Exodus seems to end in another conquest - that of the Promised Land some scholars have argued that the Hebrew tribes entered into solidarity with oppressed groups there and challenged the powers in the dominant city states that oppressed the rural populations (Gottwald 1979). This constitutes yet another example of deep solidarity.

Deep solidarity opens up a window on who God is in the Abrahamic religions: In the Exodus stories, God is not working 
from the outside, employing models of charity and advocacy; rather, God is part of the struggle. This is made clear also in the references to the Exodus in the Qur'an in Surah 26, particularly in the passage through the sea 26:61-68. Nevertheless, the dominant powers are not pushed aside here but called to conversion and repentance. Even Pharaoh gets several chances ('let my people go', Ex 5:1, 7:16, 8:1, etc.; see also Qur'an 7:105). There is always the option for the $1 \%$ to decide to join the $99 \%$ working majority.

The life of Jesus of Nazareth offers another expression of deep solidarity. He grew up in a family of construction workers who, in the Roman Empire, were often hired to work on large building projects. There, they would have experienced similar conditions to many construction workers experience today, including long working hours, lack of water and safety equipment, and no benefits. When the jobs were finished, many of these workers would be laid off, making it very likely that Jesus would have experienced unemployment as well.

Jesus embodies deep solidarity not merely because he grew up as a worker but because he never made any efforts to move 'up and out'. To the contrary, he stayed in deep solidarity with working people his whole life. His birth was first witnessed by shepherds - day labourers who tended someone else's flock. Many of his disciples were working people, several of them fishermen. Jesus' parables are full of examples from everyday labour and work, telling the stories of shepherds, who usually were not the owners of their flocks, of working women, of workers in vineyards and in fields, of fishermen and of service workers.

That one of Jesus' disciples, Matthew, reportedly was a tax collector further affirms what we mean by deep solidarity. If he was a member of the $99 \%$, Matthew realised his deep connectedness to the common people who made up the Jesus movement. If he was a member of the $1 \%$, Matthew shows that the $1 \%$ can indeed join the solidarity of the $99 \%$ and that true conversion is possible. In either case, what is very clear is that Matthew and other privileged people who were part of the Jesus movement did not convert Jesus to the 1\%; the opposite is the case: he converted them to join the $99 \%$.

The culmination of Jesus' message might be considered preaching good news to the poor (referenced several times in the gospels, for instance, Mt 11 and Lk 4). Preaching good news to the poor leads to questions like, Who 'tramples on the poor' (Am 5:11) and on working people today? Who 'takes from them levies of grain' (Am 5:11 again), including fair wages and benefits? Isn't the only good news to the poor is that they will no longer be poor? Feel-good messages, pie-in-the-sky, calls for perseverance and even handouts are not really good news.

\section{Deep solidarity and pushback}

Addressing such issues was never easy, and there are consequences. According to the Gospel of Luke, Jesus' first proclamation of good news to the poor ended with an attempt by the faith community to throw him off a cliff (Lk 4:16-30).
What seems to have enraged the community in particular, was that Jesus claimed that he would be the one bringing the good news, which was considered blasphemy.

Had Jesus merely intended to be a heroic advocate for the poor without working towards deep solidarity, his claim would have indeed been arrogant or even blasphemous. Moreover, without working towards deep solidarity, his movement might have ended abruptly if they had managed to thrown him off that cliff in Nazareth; or else it would have ended later at the point of his crucifixion. However, we interpret Jesus' story here, the reality of pushback highlights the limits of advocacy and the need for deep solidarity.

The two biggest drawbacks of advocacy are, firstly, that advocates often stifle the agency of those for whom they speak and, secondly, that advocates often overestimate their own power. The dominant powers benefit from both moves. Jesus would have scarcely been a threat to the Roman Empire of his times if he had acted alone or with a select group of radicals. And Jesus would not have been a threat had he assumed that he could do this work all by himself, like an ancient superhero.

While heroic individuals can make some difference, they will not be able to turn the tide. Deep solidarity requires us to think about the agency of all of us and what contributions we can make to the common good together. This has widereaching implications for how we understand democracy both in politics and economics. In the model of deep solidarity, elected officials, for instance, are no longer the agents of working people; rather, they are working alongside the people, putting their powers and authority to use in this context. Enlightened business leaders no longer have to guess what people might need; rather, by working alongside the people they can put their abilities to use in ways that improve the lives of workers and their communities.

The second problem, which advocates tend to overestimate their own power, is equally significant. Rarely are the dominant powers challenged by a few prominent voices. This is why these dominant powers want to have us believe that individuals like Martin Luther King, Jr., or Rosa Parks acted single-handedly. If Rosa Parks were merely some African American women who at some point got tired of segregation in public transportation and took a seat in the wrong section of a bus, her acts are heroic but not dangerous. If a pastor, however eloquent or prominent, preaches a good sermon, his act may be heroic but it is hardly dangerous either, without the support of a broader community that is well organised and active. White men who enjoy some privileges in particular often overestimate their own power, assuming that people are actually listening to what they have to say and that when they make demands or issue calls to action, things will change. Such advocacy is doomed to failure because the dominant system will not be impressed by a few dissidents, even if they band together in small groups.

Deep solidarity is necessary to create any real change. Rosa Parks, for instance, in addition to being a person of great 
courage, engaged in deep solidarity by being trained by the Civil Rights Movement and preparing for the role that she would eventually play in the Montgomery Bus Boycott. By the same token, Martin Luther King, Jr., did not invent or start the Civil Rights Movement; rather, King acted in deep solidarity with many grassroots groups that emerged all over the country in diverse locations linked to diverse organisations. This is why the movement did not end with the shooting of King, as many had hoped.

Deep solidarity helps us overcome roadblocks, including the divide-and-conquer efforts of the system. It is based on an understanding that those of us who have to work for a living, the $99 \%$ working majority, have a great deal in common. We find ourselves in the same boat, however, not because we are all alike and our differences do not matter; rather, we find ourselves in the same boat because of the dominant system and its efforts to use all of our work and labour for the accumulation of profit and gain at the very top. The clearer we are about this, the more deep solidarity becomes an option. Work and labour are what connects us, up and down the various social ladders and scales that exist among the $99 \%$. Deep solidarity is built on the awareness that we are all working people now - including the underemployed and the unemployed, the vast majority of whom would much rather work than sit idle and wait for handouts.

\section{Solidarity and diversity}

Limited forms of solidarity are often counterproductive. To some degree, capitalism does not mind narrow labour solidarity that gets pulled into the game of competition (Andrews 2012:219). Whatever success a small group of workers achieve for itself is bound to be undermined by those who are left out, whose anger and frustration is useful to the dominant system. As a result, we agree with Marcellus Andrews that 'narrow labor solidarity is no solidarity at all, but instead a road to enduring racial hatred and broad labor weakness' (Andrews 2012:223).

Deep solidarity is anything but narrow. One of its most important traits is that it does not require us to be alike or to set our differences aside (Rieger 2013b). ${ }^{6}$ Just the opposite: deep solidarity benefits from our differences brought together for the common good. Deep solidarity develops power by putting our differences to productive use while deconstructing their negative aspects. Moreover, as we put our differences to use, we begin to realise that those who are forced to endure the greatest pressures might have the most valuable lessons to teach.

Moreover, deep solidarity not only thrives on differences, it also brings to light otherwise hidden privileges and helps deconstruct them. ${ }^{7}$ The world of working people and labour is one of the best places to start because this is where all of

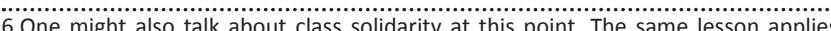
however: class solidarity does not mean being identical (sameness) but being able to put your differences to use.

7.We agree with Hancock that 'allowing privilege to remain invisible facilitates the Oppression Olympics' (Hancock 2013:127). our identities are linked most existentially and where putting them together has borne fruit in forming alternatives. Unions at their best have understood and embodied this. As W.E.B. $\mathrm{Du}$ Bois has observed: 'Probably the greatest and most effective effort toward interracial understanding among the working masses has come about through the trade unions' (Du Bois 1982:68).

Following Du Bois, race and ethnicity may serve as our first example. When white workers understand that they are workers and not bosses, they can develop a sense that they may have more in common with so-called racial and ethnic minorities than with white elites. The advantages that white working people enjoy in comparison to their minority colleagues are not insignificant, but they pale in comparison to the advantages that the white elites enjoy over white workers. White employees may indeed have the ear of white employers, receive slightly better salaries and benefits than African American, Hispanic or Asian employees and are more likely to get hired to scarce job openings. Nevertheless, their whiteness still does not put them on par with their employers, who make hundreds of times more money and whose power reflects this. White workers, like other workers, are hardly able to challenge and confront their superiors on matters of consequence. And while white people can expect to be treated better when shopping at the mall, white elites have an entirely different relationship to their suppliers.

In this situation, an awareness of deep solidarity with workers of other races can provide white workers with an opportunity to use whatever power they may have differently. White workers who have more clout with their bosses can use it in alternative fashion, for instance by putting in a good word for others or by speaking up when nobody expects it. White shoppers who are more valued have a choice either to conform or to challenge the places they frequent and to let employers know that they are paying attention to how employees are treated. In the process, the power of the $99 \%$ increases when white working people begin to listen to other working people who, because of the fact that they are forced to endure even greater pressures, might be able to see more clearly not only the problems but also the possibilities, and when they find themselves in solidarity and act accordingly (e.g. see Rieger \& Henkel-Rieger 2016). ${ }^{8}$

Using one's limited privilege differently may be the best way to deconstruct it. White power is deconstructed when white working people begin to question their ties with dominant white power and put whatever privilege they have in the service of deep solidarity with their fellow workers of racial and ethnic minorities. Divesting themselves of power or feeling guilty about one's privilege on the other hand common responses when people become aware of power and privilege - prevents a productive response. While white working people should not overestimate their own power and privilege - the whiteness of a worker by itself will not 8.We have seen these dynamics at work in our own experiences with labour and religion over the years and some of them are described in our book. 
win the battle - underestimating their power and privilege would also be a mistake.

What about gender relationships? In 2013 in the United States, women were paid 78 cents for every dollar a white man earns doing the same work, Asian American women 90 cents, African American women 64 cents, American Indian (and Alaska Native) women 59 cents and Latina women 54 cents (American Association of University Women 2014). In addition, women earn only $38 \%$ of what men earn during their prime working years between 26 and 59. As Christian ethicist Melissa Snarr has pointed out, these experiences make women's leadership in living-wage coalitions particularly valuable, especially when considering that women are often less politically active than men and view themselves as less influential (Snarr 2011:154). Deep solidarity for men, in this case, would mean to understand how their fate is actually connected more closely to women than to men of the elite groups. While a man in a heterosexual marriage may get some benefits out of being a macho or a patriarch at home, that man might benefit a good deal more if the work of his wife were to be valued by a decent income and if solidarity encouraged her to activate her own powers for the common good.

When relating to women in these new ways, men can learn how to use whatever power they have in a patriarchal world to challenge the dominant powers. This is how patriarchal power is deconstructed. Some feminist theologians have made this argument about Jesus' ways of being a man: the fact that a man spoke out against patriarchal power and in support of women must have come as a surprise, as men are expected to support other men. The dominant system was not prepared for this and neither were some of Jesus' closest followers, but this is precisely why it made a difference (Johnson 1993:126). The women of the Jesus movement, unlike the men, seemed to have learned more quickly and took on positions of leadership. This reversal of leadership is taking place not only in certain communities of faith but also in some labour unions; men do well to listen to women. Of course, using male privilege against patriarchy means to deconstruct it, as those who act in this way will not be able to rejoin the good old boys club.

It should be noted that the unions have made some progress in these areas in recent decades, as the leadership of women and minorities has grown stronger in the United States. While in the late 1980 s merely $12 \%$ of women and $15 \%$ of racial minorities were lead organisers, in 2005 that number had grown to $21 \%$ women and $22 \%$ racial minorities; women of racial minority groups now make up $7 \%$ of lead organisers (Yates 2009:155). In addition, union contracts now increasingly reference sexual orientation as a characteristic against which employers prohibited by law to discriminate (Yates 2009:162).

When race, ethnicity, gender and sexuality come together, matters become more complex yet. Deep solidarity in these relationships can only be forged if it becomes clear how all of our labour is under pressure to some degree. When jobs are sent overseas, for instance, the racism that is sometimes part of this move and that endorses treating non-whites and particularly women in other countries less well, also hurts white male workers in the United States. Likewise, when during the Great Recession, men were sometimes laid off before women, the sexism in this move as women provide cheaper labour then men ends up hurting men as well.

Deep solidarity in these cases can prevent us from blaming the victims (international workers and women), identify where energy and agency are found and direct our agency to where it can make a difference. In organising poultry workers in the South of the United States, for instance, African American workers were in a better position (because of their traditions and their citizenship) to speak out against unfair labour practices when compared with immigrant workers from south of the border. This made multi-racial and ethnic dialogues essential (Slessarev-Jamir 2011:118). While many white American men who belong to the $99 \%$ working majority still need to learn some painful lessons about the limits of their power, they can now employ their limited power in different ways, such that the community benefits rather than the elites.

For relatively privileged members of the middle class who have to work for a living, everything changes when they become aware of deep solidarity. Now they can put some of their privileges to use so that they will actually make a difference, reshaping their identity in the process. Instead of using their education for shoring up the position of the $1 \%$, college-educated people can now put their expertise and knowledge to work for the well-being of the $99 \%$. All areas and fields of study are useful: how do we assess the current political, financial, psychological, social, cultural, scientific and religious situations? What alternatives might there be when these inequities sink in and a substantial number of people shift their allegiances?

Still, the middle class will not be able to do any of this without the input and guidance of those who are less privileged. While deep solidarity reminds us that we are in the same boat, we must never forget that some are worse off than others. Those who feel the pressures of the system most acutely are the ones who have no reserves, who financially depend almost exclusively on their income from work and who are therefore predisposed to see and feel more clearly the challenges of what is going on.

Deep solidarity that puts diversity to work gets a boost when we look at it from the perspective of labour. Here is where everything comes together: race, ethnicity, gender, sexuality, age, etc. The need to work for a living ties us into concerns of many of the popular movements, including the Occupy Wall Street movement - realising the fundamental difference between the $1 \%$ and the $99 \%$ - and the Black Lives Matter movement - as black lives are destroyed in ways that include what is happening at work or in the lack of work. The concerns of immigrants also need to be understood in terms of work: the majority of immigrants who come to the United 
States are in search of work, forced to do so because of great economic hardships at home. Even human trafficking, perhaps one of the most heinous crimes of our time, is tied to work, as most human trafficking turns out to be labour trafficking. Likewise, wage theft and the lowest rungs of wage depression are often tied to racism, ethnocentrism and sexism.

In this light, deep solidarity can be seen as a matter of life and death. As the lack of solidarity kills people every day, deep solidarity can help us to find the power and the energy to make a difference and to preserve life. Work, as a result of the fact that we are spending too much time at it and that its pressures affect us more deeply than we ever imagined, welds us together at many levels. Minds, hearts and bodies are all involved. As one of my graduate students, Ben Robinson, once put it: 'We may march together, we may work together, but we are not in solidarity until we feel together'.

\section{Conclusion}

Deep solidarity, to recap, helps us to take into account and make use of the fact that the $99 \%$ have more in common with each other than with the $1 \%$. This allows for more effective action and collaboration without erasing differences, including religious differences (see Rieger \& Henkel-Rieger 2016:96-99). ${ }^{9}$ As we recognise our deep connectedness that is most visible at work, work assumes a transformative character. Even political, economic and religious activism can now be seen as linked to part of our everyday work rather than something that belongs to leisure time. All activism is informed and energised by our work, and both the pressures and the potential of work contribute to this.

While the $99 \%$ working majority are together in this, whether they are aware of it or not, it is not necessary to expect that everybody will join us. In fact, because things are urgent, it would not be wise to waste too much time on those who are not ready yet. Instead, we need to connect with those growing numbers of people who are waking up every day, realising that they have less and less power in their jobs and their lives and that something needs to change. These people come from all walks of life, from various races, genders, sexualities, from farm workers toiling in the hot sun all day to lawyers slaving away for billable hours. A certain critical mass is needed for change to happen, of course, but it will not take $99 \%$ of the $99 \%$. Some say that only $3 \%$ of the population is enough to bring change.

The best news yet is that solidarity is not merely a pious ideal which does not exist in reality and therefore would have to be produced artificially. Deep solidarity is not primarily based on the moral exhortation that people ought to work together: it is about observing relations that are already in place and finding common roots in our experiences as working people, both positively and negatively. As a result, all we need to do is help people deepen their budding senses of what is going on and that capitalism pushes us into the same boat, whether we are aware of it at first or not. The ask is simple when it comes to deep solidarity: become aware of it, experiment with it, explore it at various levels and above all, resist any efforts to be divided and conquered once again.

\section{Acknowledgements Competing interests}

The authors declare that they have no financial or personal relationships which may have inappropriately influenced them in writing this article.

\section{Authors' contributions}

J.R. and R.H-R. equally contributed to the research and writing of this article.

\section{References}

American Association of University Women, 2014, By the numbers: A look at the gender pay gap, AAUW Empower, Women 1881.

Andrews, M., 2012, 'On economics and labor solidarity', in R. Greenwald \& D. Katz (eds.), Labor rising: The past and future of working people in America, pp. 214226, The New Press, New York.

Du Bois, W.E.B., 1982, Writings by W.E.B. Du Bois in Periodicals Edited By Others, Kraus-Thomson Organization, Millwood, NY.

Gottwald, N.K., 1979, The Tribes of Yahweh: A sociology of the religion of liberated Israel, 1250-1050 B, C. E. Orbis Books, Maryknoll, NY.

Hancock, A., 2013, Solidarity politics for millennials: A guide to ending the oppression Olympics, 2011 edn., Palgrave Macmillan, New York.

Johnson, E.A., 1993, 'Redeeming the Name of Christ', in C.M. Lacugna (ed.), Freeing theology: The essentials of theology in feminist perspective, Harper San Francisco, San Francisco, CA.

Martinot, S., 2003, The rule of racialization: Class, identity, governance, 1st edn., Temple University Press, Philadelphia, PA.

Martinot, S., 2010, The Machinery of Whiteness: Studies in the structure of racialization, Temple University Press, Philadelphia, PA.

Rehmann, J., 2013, 'Poverty and poor people's agency in high-tech capitalism', in J. Rieger (ed.), Religion, theology, and class: Fresh engagements after long silence, pp. 147-152, Palgrave Macmillan, New York.

Reuters News Report, 2017, 'The World's 8 Richest men are now as wealthy as half of the world's population', Fortune Magazine, 15 January 2017, viewed 28 March 2017, from http://fortune.com/2017/01/16/world-richest-men-income-equality/

Rieger, J., 2012, 'Occupy wall street and everything else: Lessons for the study and praxis of religion', Peace Studies Journal 5, 33-45.

Rieger, J. (ed.), 2013a, Religion, theology, and class: Fresh engagements after long silence, 2013 edn., Palgrave Macmillan, New York, NY.

Rieger, J., 2013b, 'Instigating class struggle? The study of class in religion and theology in the United States and some implications for race, gender, and ethnicity', in J. Rieger (ed.), Religion, theology, and class: Fresh engagements after long silence, 189-211, Palgrave Macmillan, New York.

Rieger, J. \& Henkel-Rieger, R., 2016, Unified we are a force: How faith and labor can overcome America's Inequalities, Chalice Press, St. Louis, MO.

Rieger, J. \& Pui-lan, K., 2013, Occupy religion: Theology of the multitude, Reprint edn., Rowman \& Littlefield Publishers, New York.

Rose, F., 1999, Coalitions across the class divide: Lessons from the labor, peace, and environmental movements, 1st edn., Cornell University Press, Ithaca, NY.

Slessarev-Jamir, H., 2011, Prophetic activism: Progressive religious justice movements in contemporary America, NYU Press, New York.

Snarr, C.M., 2011, All you that labor: Religion and ethics in the living wage movement. Religion and social transformation, New York University Press, New York.

Standing, G., 2016, The precariat: The new dangerous class, Reprint edn., Bloomsbury Academic, London.

Weinstein, M., 2012, The difference between a million and a billion dollars [with graphic] [WWW Document], Smarter Invest, viewed 10 August 2015, from http:// investing.covestor.com/2012/07/the-difference-between-a-million-and-a-billiondollars-graphic

Wesley, J., 1986, 'Thoughts on the present scarcity of provisions', in T. Jackson (ed.), The Works of the Rev, John Wesley, Hendrickson, Peabody, MA.

Wood, D.C., 2010, 'The church, The union, and the trinity', in J. Heine \& C. Brooke (eds.), A worker justice reader: Essential writings on religion and labor, Orbis Books, Maryknoll, NY.

Yates, M.D., 2009, Why unions matter, 2nd New, Rev., Updated edn., Monthly Review Press, New York. 